\title{
America's new racial politics: white protectionism, racial reparations, and American identity
}

\author{
Rogers M. Smith ${ }^{1}$ (D) . Desmond King ${ }^{2}$
}

Received: 15 September 2020 / Accepted: 3 November 2020 / Published online: 16 November 2020

(C) The Institute of International and Strategic Studies (IISS), Peking University 2020

\begin{abstract}
The United States has been shaped by clashes between rival "racial orders" or "racial policy alliances" since the nation's very beginning. For the last half century, those contests have chiefly been between proponents of "color-blind" and "raceconscious" public policies. Today, however, the nation's dominant racial policy alliances are transforming into ones centered on significantly new themes. The racially conservative "color-blind" policy alliance is, under the leadership of President Donald Trump, becoming an alliance promising "white protectionism." The "race conscious" policy alliance is, with the mobilizations around the slogan of Black Lives Matter, becoming an alliance focused on "racial reparations" to end "systemic racism". These new, even more polarized racial policy alliances have counterparts across the globe, and they are likely to shape political life for many years to come.
\end{abstract}

Keywords Color-blind · Race-conscious · Donald Trump · Black lives matter · White protectionism $\cdot$ Racial reparations $\cdot$ Systemic racism

\section{Preface: the origins and structures of American racial politics}

The United States today is undergoing a significant transformation in its racial politics of such a scale that it has brought the nation to a critical juncture. But as many scholars have shown, especially the pioneering African American historian John Hope Franklin, America's racial contests have deep roots that date back well before the nation itself (Franklin and Higginbotham 2010).

Rogers M. Smith

rogerss@sas.upenn.edu

Desmond King

desmond.king@nuffield.ox.ac.uk

1 University of Pennsylvania, Philadelphia, USA

2 Nuffield College, Oxford University, Oxford, UK 
After the English established plantations in Ireland in the fifteenth century, their next overseas colonies came in North America, in Nova Scotia and Virginia in the early $1600 \mathrm{~s}$. Although early relations with Native Americans were complex and occasionally included collaboration over common areas (Greer 2017), the dominant trend quickly became one of land dispossession and resultant conflict (Frymer 2017). To grow crops in their Virginia colony, the English experimented with enslaving Native American tribespeople, but this initiative proved abortive because the Native Americans not only resisted violently, but also could and did escape home.

The English colonists started importing Africans to serve as forced laborers in 1619. That worked out better for the colonists, because though the Africans also resisted, they could not get home. By 1700, the practice of African American enslavement was present throughout most of British North America, defended by most preachers, political leaders, and popular opinion among the colonists, even though some also said it was unjust. The southern British colonies particularly came to depend on enslaved labor to plant and harvest tobacco, rice, and indigo.

As the colonies became more prosperous, the British imperial authorities began taxing and regulating them more extensively to pay the costs of empire and to guarantee that spoils of colonialism enriched the British Isles. Cities such as Bristol, Glasgow, and Liverpool, in addition to many parts of London's docklands, expanded and prospered from the income generated through the slave trade and enslaved labor in the colonies. The taxation and regulations were bitterly resented in the "New World". In Philadelphia in 1776, angry dissidents representing 13 colonies proclaimed their independence and began a war to make it a fact. In that same city the year before, the Religious Society of Friends, commonly known as the Quakers, organized the first American society devoted to a different form of independence: liberation of Africans from enslavement. In the course of the American Revolution, British authorities offered enslaved African Americans freedom if they would join the British side, and many did. Some northern colonies that were not so dependent on enslaved labor countered with similar promises, and more Americans began to argue that their revolutionary commitment to human liberty was inconsistent with human enslavement. As the new nation won independence, many northern states adopted gradual emancipation statutes to end chattel slavery over the next generation. Many southern states, however, held fiercely to their "peculiar institution".

Those who created the U.S. Constitution in Philadelphia in 1787 therefore felt they had to make fateful compromises. Their Preamble promised the "blessings of liberty" to "We the People of the United States", but their Constitution went on to classify every enslaved person as $3 / 5$ ths of a human being, counting each as a resident of each state and so increasing the size of the slave states' delegations in the House of Representatives and the Electoral College. Some members of the Constitutional Convention feverishly clung to the hope that enslaved labor would soon prove unprofitable, which might mean that the practice would die away. However, in 1793, a young Yale College graduate, Eli Whitney, invented a new technology, the cotton gin, that made raising cotton via enslaved labor far more productive and profitable. Cotton and slavery soon became the greatest sources of wealth in the American South, with powerful tentacles well beyond that region-including the slave trade in which individuals and institutions throughout the land invested, the northern textile 
mills, and the financial industry in New York, which issued bonds based on plantation enslavement wealth (Holden-Smith 1993; Hudson 2017).

In these ways, Americans who legally designated themselves as "white" created a nation that from the outset promised liberty to all but rested in significant part on exploitation of African Americans and other people of color. They thereby created a politics structured from the outset by clashes between Americans who thought this exploitation legitimate and those who did not. In our previous works, we have chronicled how the resulting racial politics has been a crucial driver of much in American political development.

We have argued that it is useful to analyze the overall structure of American racial politics by mapping how political actors have generally felt driven to join with one side or another of what we have termed "racial institutional orders" and "racial policy alliances" (King and Smith 2005, 2011). These synonymous terms refer to broad political coalitions joined by their stances on the major racial policy issues defining their eras. We sometimes call those coalitions "alliances" to stress their character as loose networks of groups and actors pushing in the same policy directions, sometimes "institutional orders" to stress that the alliances include governing institutions and officials who authoritatively shape people's lives in line with their racial visions.

Until recently, American political development displayed three sets of racial orders or alliances. Pro-slavery versus anti-slavery coalitions did much to shape American politics from the Revolution through the Civil War. The Civil War ended enslavement but did not excise pro- and anti-racist sentiments. Consequently, proracial segregation and anti-segregation coalitions arose and were central to American life from the late nineteenth century through the mid-1960s. From the late 1970s up to now, racial conservatives who formerly supported segregation rebranded themselves as adherents of a "color-blind" approach to any federal reforms tackling racial inequality, in opposition to the "race-conscious" measures that were becoming central to the agendas of many civil rights activists.

Although many of those activists had themselves championed color-blindness in opposition to racial segregation, most soon concluded, as some had long insisted, that real progress for people of color required substantial race-targeted initiatives. Though realistic, that policy position shifted the political advantage back to those racial conservatives who were willing to modify their views, at least publicly. "Color-blind" commitments appear race neutral. Especially in a nation with America's distinctively strong traditions of individualism, it sounds fair for no person to gain advantages or penalties because of their race-and for those unfamiliar with the rest of his thought, "color-blindness" resonated with Dr. Martin Luther King, Jr.'s instruction not to judge persons by the color of their skin. Yet because America has also had strong traditions of white supremacy fostering deeply entrenched inequalities, insisting on color-blindness means in practice the maintenance of many disadvantages of the nation's people of color. As a result, since the 1960s most racial conservatives have recognized that they can both defend their interests and regain the high ground in the popular mind by professing principled dedication to color-blindness.

This racial conservative mantra has not entirely prevailed. Proponents of colorblindness and race-conscious measures have controlled various contesting American 
federal, state, and local governing agencies over the last half-century. Still, since the Reagan Revolution of 1980, the color-blind racial policy alliance has had the upper hand.

By the early twenty-first century, the color-blind policy alliance had slowed elementary and especially high school desegregation, so that re-segregation rose markedly; limited affirmative action in university admissions and public hiring and contracting; weakened protections against racially disparate vote suppression; and largely abandoned the use of the federal U.S. Housing and Urban Development's money to enforce affordable housing quotas and affirmatively pursue fair housing. Republican presidents' success in populating the Supreme Court with a narrow majority favoring color-blind precepts aided and abetted all these policy developments, often in 5-4 decisions. These include the ban on school racial integration in Parents Involved in Community Schools v. Seattle (551 U.S. 701, 2007) and the egregious crippling of the Voting Rights Act in Shelby County v. Holder (570 U.S. 529, 2013).

In so doing, the color-blind racial policy alliance aided those white Americans who wished to see many of their systemic advantages continue. Consequently, for decades after the passage of the civil rights laws of the 1960s, even many of those who still identified with the nation's traditions of white supremacy found it politic to join publicly in support of policymaking "without regard to race". That stance seemed necessary to stave off proponents of measures to lessen the disadvantages of non-white Americans and to ensure that even if African Americans gained great political power, as Barack Obama eventually did, they would be reluctant, as Obama was, to make race-conscious initiatives central to their governance (Bryant 2017).

Today, however, circumstances are changing. America is witnessing a fundamental transition in the structure of its racial politics. The U.S. has embarked on a political period defined by a still more polarized opposition between racial conservatives rallied to "white protectionism", explicitly mobilized to preserve or enhance existing white advantages, and racial reformers acting to end "systemic racism" through "racial reparations" that aim to go far beyond now-traditional affirmative action programs. Whatever the results of the 2020 election, these new racial policy alliances may long endure and structure American politics.

\section{American's new racial politics: white protectionism}

Despite Barack Obama's reticence on racial issues, perhaps the single most important factor in changing American racial politics was his election to the White House for what proved to be an 8-year incumbency. Perhaps the second most important factor was that after 2012, dissatisfaction with slow progress followed the high hopes Obama had stirred, compounded by mounting evidence of racist police brutality. The result, starting in 2013, was the Black Lives Movement. Both these developments heightened the fears of many white Americans that the racially conservative era that had prevailed since 1980 was over, putting them and their accustomed advantages in danger. 
The shifts in America's racial orders initially surfaced in the first 2 years of the Obama administration, when virulent opposition to the president and his policies erupted, including the overwhelmingly white Tea Party, which cost Democrats control of Congress in 2010, and the Donald Trump-led "birther" movement that sought to deny Obama's citizenship (Jardina and Traugott 2019). A new or (more probably) latent group of "white identity"-conscious voters believed that whites increasingly were victims of discrimination because Obama's America was excessively "politically correct", only concerned about racial minorities (Jardina 2019).

To be sure, their concerns did not begin with Obama. A 2011 study found that while both black and white Americans believed anti-black bias had declined from the 1950s through the 2000s, many whites thought anti-white bias had risen through those decades, eventually becoming more extensive, in their eyes, than anti-black bias. By 2017, 55\% of whites believed that whites suffer discrimination in modern America (though most believed racial minorities faced discrimination as well) (Gonyea 2017). Those who viewed whites as discriminated against opposed not only race-conscious policies, but also all ostensibly race-neutral policies that they saw as aimed chiefly at aiding non-whites, thereby victimizing whites.

This rising white ethnic identity was the fodder for the Trump movement's success in 2016. Popular receptivity to three elements of the Trump campaign shifted color-blind commitments toward white protectionism: a more militant rhetoric that eschewed mention of color-blind principles and spoke often of protection; a new strategic emphasis on the special victimization of white Christians; and a ruthless pursuit of civil right policy reversals.

Rhetoric: we have recently argued that in 2016, Trump made it clear that his focus would never be on redressing America's injustices against people of color (Smith and King 2020). He condemned Obama for "speaking up about America's past errors" (Trump 2016a). He attacked "those peddling the narrative of cops as a racist force in our society" as "hurting" law-abiding Americans, and he praised the police as "the line separating civilization from chaos" (Trump 2016b, c). He especially tweeted accounts of white victims of crimes perpetrated by blacks, twice retweeting from a Twitter user called "WhiteGenocideTM" (Confessore 2016). And Trump advanced a "new civil rights agenda for our time" that featured, above all, safety provided by strong policing; school choice; and deregulation to promote jobs-not rigorous anti-discrimination enforcement, much less race-targeted measures (Trump 2016d). Though the official message was that Trump would protect all Americans against criminal violence, many heard something different. Counties that hosted Trump rallies saw a $226 \%$ increase in racial and religious hate crimes in ensuing years (Feinberg et al. 2019).

Many of those hate crimes were perpetrated by white supremacist groups, newly emboldened by confidence that the nation's leader was directly serving their side. Trump, to be sure, occasionally says he disavows white supremacy and white nationalism; but he has repeatedly defended those marching under their banners, retweeted their messages, and appointed people long associated with them to public offices (Collins 2020). Trump does frequently describe himself as a nationalist, and he, like his former adviser Steve Bannon, frequently expresses solidarity with authoritarian nationalist leaders and movements around the world, most of whom stress not only 
national sovereignty, but also the desirability of maintaining the superior position of their dominant ethnocultural groups (Hart 2020). The recent resurgence of ethnocultural nationalisms and associated intolerance in states is a global phenomenon that reinforces the sense of Trump and many of his supporters that they are the future.

Relatedly, the white supremacists committing hate crimes often also see themselves as part of an international movement (Rose and Soufan 2020). Few now justify their actions by invoking color-blindness. They claim that they, like Trump, are protecting whites against global forces of injustice. In the summer of 2020, many private militia groups, some explicitly white nationalist, began confronting Black Lives Matter (BLM) protestors in American cities to "protect" against urban violence, often by escalating it (Stanley-Becker 2020).

They often did so in the name of Donald Trump, a practice he did nothing to discourage. Instead, as his catastrophic bungling of the COVID-19 crisis caused his approval ratings to plummet in the polls after March 2020, he responded by ratcheting up his protectionist rhetoric, promising not public health but safety against BLM protestors and policies that might promote suburban integration. Over the July 4th weekend, Trump promised to defeat what he termed "a new far-left fascism" that sought to destroy "our national heritage", such as statues of his hero Andrew Jackson (Trump 2020a). He called painting "Black Lives Matter" in front of Trump Tower in New York City a "symbol of hate" (Liptak and Holmes 2020). He attacked Obamaera efforts to promote low-income, racially integrated housing in America's suburbs, contending he was protecting "the American dream" of, apparently, the comfortable race and class suburban segregation he presumed American whites sought (Karni et al. 2020). He threatened to veto plans supported by even most Republicans to change or remove the names of Confederate generals from military bases (Demerjian 2020). He refused to criticize self-proclaimed militia members who invited themselves to Black Lives Matter protests and used the resulting confrontations to justify shooting demonstrators (Beauchamp 2020). In his speech accepting the 2020 Republican nomination for the presidency, Trump repeatedly promised to "protect" Americans. The closest he came to advocating for color-blind policies, however, came when he briefly said he would "ensure equal justice for citizens of every race, religion, color, and creed", a promise he immediately specified by focusing on "religious liberty" and "the right to bear arms", which he said he had "totally protected" (Trump 2020b). Again and again during the 5 years since he announced his first presidential campaign, Trump sought to mobilize racial conservatism not around color-blindness but white protectionism.

Strategy: mobilizing historical tropes and passions has to be done subtly. Even for Trump, it is politically unwise to speak too explicitly of white protectionism, much less white supremacy, as pre-World War II American leaders often did. Early in his campaign, however, Trump found he did not need to do so. He learned that he could gain ardent support by promising explicitly to protect Christians against unjust liberal abuses and by making this promise primarily to conservative white Christians. In 2016, Trump assured a rally of such Christians that in his administration, "Christianity will have power", boasting, "if I'm there...you don't need anybody else" (Dias 2020). His nomination acceptance speech criticized the 1954 Johnson amendment depriving "religious institutions" of their tax-exempt 
status "if they openly advocate their political views", saying their "voice has been taken away" (Trump 2016e). He went on to tell Christian groups: "Christian faith is not the past but the present and the future" of America. He contended that "our media culture often mocks and demeans people of faith", and that "our politicians have really abandoned you." Trump promised instead that under his administration, "Christian heritage will be cherished, protected, defended, like you've never seen before" (Trump 2016f, g).

By 2020, most of America's evangelicals believed Trump had fulfilled these promises beyond their expectations. They saw him as Christianity's Great Protector, and they were clear on which Christians he was protecting. Interviewed by The New York Times, one Trump supporter contended that it had been "dangerous" to be Christian under Obama because "all of the problems of America" were blamed on "the white believers". Another contended that in the Obama years, "our freedoms" were "slowly being taken away", and that "Caucasian-Americans" were "becoming a minority. Rapidly" (Dias 2020). These supporters displayed no doubt that when Trump promised to protect Christianity, he was also promising to protect America's whites. Many appeared to have their senses of white identity heightened by Trump's accounts of their victimization. Many also saw America as fundamentally a white Christian nation, and they were willing to forgive all the sins of those who, like Trump, they saw as committed to defending that vision.

Policies: Trump's policies have done so, implementing white protectionism in two stages. First, he has consistently appointed opponents of policies of aid for communities of color to key positions within Cabinet agencies and the federal judiciary. Trump's secretary of Housing and Urban Development (HUD), Ben Carson, opposes remedial housing policy. Trump's first Attorney General, Jeff Sessions, previously used his position as Alabama's attorney general to defend that state's postBrown de facto segregated education system. He also sounded alarms about vote fraud and affirmative action policies. Sessions' successor, William Barr, has called the Black Lives Movement "Bolsheviks" with "fascistic" tactics and accused one of its members of "treason" (Peiser 2020). No figure has been more important in shaping the administration's policies on immigration and a range of related policy issues than Stephen Miller, whose ties to white nationalists have drawn wide criticism, but not from Donald Trump (Holpuch 2019).

Second, these Trump appointees and their president have systematically reversed decades of civil rights rules, combating erosion of white privileges and weakening the position of communities of color. Examples include (Smith and King 2020):

- siding with lawsuits against universities' affirmative action programs;

- stripping the Consumer Financial Protection Bureau's Office of Fair Lending and Equal Opportunity of enforcement powers against discrimination in credit lending;

- ending the Equal Employment Opportunity Commission's rule requiring companies to report pay by sex, race, and ethnicity to identify discriminatory patterns;

- creating a new bureau to investigate naturalized Americans for cases of ineligibility;

- establishing a commission on voter fraud in November 2016, which found none; 
- supporting states' new voter ID laws that facilitate racially disparate vote suppression;

- abolishing Justice Department advocacy of consent decrees to monitor police forces' discriminatory practices;

- stopping HUD and the Justice Department from filing Fair Housing disparate impact suits to combat racial discrimination;

- ending the Obama-era "Affirmatively Furthering Fair Housing" rule requiring localities to evaluate and remedy barriers to housing choice;

- supporting school districts' releases from court desegregation orders despite persisting patterns of racial segregation;

- refusing to combat the rise of right-wing extremist groups, while using the label "domestic terrorism" only on left-wing activists, despite evidence that rightwing groups, often white supremacists and Christian nationalists, committed far more violence (Inskeep et al. 2020);

- terminating federal diversity training programs, which taught, consistent with critical race theory, that American whites benefit from the nation's systemic racism (Shaw 2020).

Though previous Republican administrations have supported similar policies, none has pursued them so forcefully or consistently. Unlike their predecessors, moreover, Trump and his officials do not stress that they are upholding color-blindness. They boast that they are reversing liberal Obama policies that failed to protect Americans —or at least, some Americans.

\section{America's new racial politics: racial reparations}

Just as this "white protectionism" represents a significantly new emphasis on a long-present theme of racial conservatives, used to justify more militant policies and tactics, so the recent focus on "racial reparations" and "systemic racism" elevates to greater prominence positions long held by advocates for people of color. Black nationalists from Bishop Henry McNeal Turner in the late nineteenth century through the Nation of Islam and the Black Panther Party in the 20th have prioritized reparations, invoking the unfulfilled Civil War promise of "40 Acres and a Mule". In 1955, as the modern civil rights movement gained momentum, Audley "Queen Mother" Moore founded the Reparations Committee of Descendants of United States Slaves. Though it had limited impact, it kept the African American reparations cause alive. Then the push in the late 1980s for Congress to compensate Japanese-American internment camp survivors helped spark the formation of the National Coalition of Blacks for Reparations in America (N'COBRA), which has been active ever since (Henry 2003, 137-142; Biondi 2003, 6-8). In 1989, U.S. Representative John Conyers began repeatedly introducing H.R. 40 to create a commission to study and develop reparations (Biondi 2003, 11; Henry 2007, 97, 118). Now sponsored by Rep. Sheila Jackson Lee, the bill has long had the support of mainstream civil rights groups like the National Association for the Advancement of Colored People (NAACP), the Leadership Conference for Civil Rights, and the 
Southern Christian Leadership Conference. Most Democratic presidential candidates endorsed it in the 2020 campaign, including, after a history of skepticism, eventual nominee Joe Biden (Lillis and Wong 2019; Gambino 2020).

Nonetheless, reparations calls remained at the margins of American racial politics until recently. Google Trends indicates that after a flurry of attention in the early 2000s stirred by Randall Robinson's book, The Debt (Robinson 1999; Henry 2003, 143-144), and his organization with Harvard Law Professor Charles Ogletree, Jr. of the Reparations Coordinating Committee (Newburger 2020), discussion of reparations waned over the next 15 years (Google Trends 2020). The topic has spiked sharply since 2018. Still, few major civil rights groups have yet made it a top priority, instead continuing to urge a more traditional agenda that includes affirmative action in education and employment, criminal justice reforms, health care, voting rights, racial environmental justice, and other issues (e.g., NAACP 2020; Leadership Conference on Civil and Human Rights 2020). Moreover, while under Trump "white protectionism" has become the program of a power-wielding "racial institutional order," at this point supporters of reparations are for the most part simply a "racial policy alliance," in control of relatively few governing offices.

Yet it is not too soon to say that talk of reparations is moving to the center of the political stage, whether or not it ultimately succeeds in becoming the governing message there. An important spur came from Ta-Nehisi Coates' 2014 Atlantic article, "A Case for Reparations" (Coates 2014)_-published a month before the killing of Michael Brown in Ferguson, Missouri. Both events propelled the remarkable growth of the Black Lives Movement. It is now a familiar story about how a Twitter hashtag formed in 2013 by Patrice Cullors, Alicia Garza, and Opal Tometi out of outrage at the acquittal of George Zimmerman for the murder of Trayvon Martin soon blossomed into an enduring nationwide, indeed, global movement (Rickford 2016, 34). Though its tactics, decentralized organization, and agenda all have critics from the left as well as the right, the Black Lives Matter Global Network now includes 16 chapters in the U.S. and allied groups throughout much of the world (Szetela 2019; Black Lives Matter 2020). Some analysts contend that the protests in its name during 2020 have been the largest in U.S. history (Buchanan et al. 2020). Polls show, moreover, that in the summer of 2020, over $60 \%$ of all Americans expressed support for Black Lives Matter, and even more saw their nation's criminal justice system as marred by racial injustices - though most Republicans disagreed and over $60 \%$ of all Americans expressed opposition to reparations (Langer 2020). As more protests began to give way to late-night looting and violent confrontations with right-wing militia vigilantes by the fall of 2020 , moreover, opposition to Black Lives Matter rose, though the movement retained majority support (Wise 2020).

That opposition is highly significant, because as BLM activism has heightened, its agenda has broadened to include efforts aimed against all forms of systemic racism. Confronted by a seemingly endless stream of camera-recorded horrors, including the killing of George Floyd in May 2020, the movement has never lost its original focus on police brutality toward African Americans. Its goals now go beyond criminal justice, however, to encompass all that can help Black people around the world to "eradicate white supremacy" in every form, and it condemns sexism, ageism, narrow nationalism, and homophobia as well as racism 
(Black Lives Matter 2020). It is also a partner with roughly 50 other groups in an umbrella organization, the Movement for Black Lives (M4BL). In 2016, M4BL adopted a broad-ranging platform that explicitly features reparations, along with demands for Black self-determination; community control; restructuring of the economy to serve people and not corporations; investment in health care, housing, and education in Black communities; and more (Movement for Black Lives 2020).

The platform also defines reparations expansively. It does not focus on individual payments to those directly harmed by slavery or segregation. Instead it calls for free access to higher education and forgiveness of student loans; a guaranteed minimum income for all Black people; corporate and government payments to Black communities to support health care, housing, food, and land; and revisions in public school curricula and cultural and historical sites to recognize enslavement, segregation, and discrimination and to honor struggles against such oppressive institutions. When journalists write that "systemic racism" has become the "phrase du jour", they mean that the Black protest agenda has become more visibly concerned to address the racial injustices that are built into a wide range of economic, political, medical, educational, cultural, and social systems (Worland 2020). Though some proponents of reparations, such as Nikole Hannah-Jones, still include individual payments among their priorities, most now are willing to label all means of combating systemic racism as reparations (Hannah-Jones 2020). Their proposals have not yet been enacted into public policies, as "white protectionism" positions have been under Trump; but they do provide an extensive agenda for combatting "systemic racism" should "racial reparationists" gain greater political power.

Both M4BL and BLM stress how Black oppression is a global phenomenon, rooted in the age of white imperialism and pervasive in the nominally postcolonial era (Movement for Black Lives 2020; Black Lives Movement 2020). Racism infuses the treatment of migrants of color in many Global North countries. M4BL and BLM are allied with hundreds of organizations around the world, and the slogan of Black Lives Matter has been prominent in protests in South America, Europe, the Middle East, Africa, Asia, Australia, and New Zealand (Kirby 2020; Harris 2020). As in the case of white protectionists, confidence that they are part of a surging global phenomenon has heightened the boldness of proponents of reparations in the U.S., while persuading many to join them.

At this point, both the language of reparations and many proposals urged under that heading still go too far for a majority of Americans. Nonetheless, receptivity toward them has increased. On July 14th, 2020, the City Council of Asheville, North Carolina, a southern city that is $83 \%$ white, voted unanimously to apologize for the city's past complicity in slavery. More significantly, the Council created a Community Reparations Commission tasked to recommend funding to increase minority home ownership and aid minority businesses (Pereira 2020). The mandate neither included nor ruled out payments to individuals. Asheville followed the lead of Evanston, Illinois, which decided in November 2019 to adopt a new tax to fund housing and employment opportunities for its African American residents. Providence, Rhode Island and Richmond, Virginia, among other cities, are considering similar measures (Fies 2020). 
In addition to these cities, higher education institutions like Georgetown University and the Princeton Theological Seminary have acknowledged their past complicity in slavery and sought to aid those victimized by the institution, in Georgetown's case by directly paying descendants of people it owned and sold. Catholic nuns in Louisiana are doing the same (Jones 2020). Many of the progressive Democratic candidates who fared well against establishment figures in 2020, like New York's Jamaal Bowman, have strongly affirmed the justice of reparations (Lee 2020). Economist William Darity therefore calls the surge in political receptivity to reparations a "sea change", even if America remains far from the concerted and focused federal action he sees as needed (Goldberg 2020; Darity and Mullen 2020). In agreement, we conclude that in the 2020s, most allying in pursuit of egalitarian racial reforms in America will feel empowered and impelled to advance a demanding agenda that merits the label "racial reparations".

\section{Conclusion: the prospects for peril and progress}

On its face, this shift of the dominant positions in American racial policy debates toward racial reparations and white protectionism, though far from complete, represents a disturbing deepening of longstanding and profound American racial divides. Because of the prominent role Donald Trump has played in these developments, there is a chance that this trend will not endure after he departs the White House, whether he does so in 2021 or 2025 (leaving aside more unconventional possibilities). Many analysts believe, however, that the post-Trump GOP will be led by successors who will claim his mantle. At this writing, potential candidates hoping to do so, including Vice President Mike Pence, Secretary of State Mike Pompeo, Senators Tom Cotton and Josh Hawley, and Governor Ron DeSantis, are numerous (Brownstein 2020). Though most might not promise white protectionism as crudely as Trump has done, all are likely to present the agenda of racial reparations to end systemic racism as radical and dangerous, perhaps as racist "far left fascism". Many Democrats, moreover, perceiving a radical "racial reparations" agenda as a political liability, may seek in practice to confine efforts to combat systemic racism to something close to the moderate civil rights agenda they have pursued since the 1970s.

However, the pressures to do more are now greater than they have ever been. Consequently, it is likely that most Democratic candidates-and most Americans who see themselves as at least moderately liberal, especially on racial issues-will continue to endorse Black Lives Matter and to support studies of different forms of reparations, looking for varieties they can safely support. If they identify policies on race-related issues that have broad appeal, then in the next era of American racial politics, unlike the current one, it may be the policy alliance that proposes transformative egalitarian reforms that gains predominance.

Funding Research for this paper has not relied on any external funding. Funding support came from research funds for the chairs held by the authors at their respective universities. 


\section{Compliance with ethical standards}

Conflict of interest The authors have no conflicts of interest. They have equally contributed to and are equally responsible for its contents. Neither funding nor any other affiliations of the authors present any conflicts of interests.

Ethical statement This article is the joint product of its two authors in both design and execution. The research for the article relied on publicly available text sources and did not require Institutional Review Board approval.

\section{References}

Beauchamp, Zack. 2020. Donald Trump is inciting violence. Vox. https://www.vox.com/2020/9/1/21409 037/trump-protest-riots-kenosha-violence-incitement. Accessed 29 Oct 2020.

Biondi, Martha. 2003. The rise of the reparations movement. Radical History Review 87: 5-18.

Black Lives Matter. 2020. About. https://blacklivesmatter.com/about/. Accessed 29 Oct 2020.

Bryant, Nick. 2017. Barack Obama legacy: did he improve US race relations? BBC News. https://www. bbc.com/news/world-us-canada-38536668. Accessed 29 Oct 2020.

Brownstein, Ronald. 2020. Why Republicans still can't quit Trump. The Atlantic. https://www.theat lantic.com/politics/archive/2020/06/republicans-2024-nominee-will-be-trump-acolyte/612925/. Accessed 19 Oct 2020.

Buchanan, Larry, Quoctrung Bui, and Jugal K. Patel. 2020. Black Lives Matter may be the largest movement in U.S. history. New York Times. https://www.nytimes.com/interactive/2020/07/03/us/georg e-floyd-protests-crowd-size.html. Accessed 29 Oct 2020.

Coates, Ta-Nehisi. 2014. A case for reparations. The Atlantic. https://www.theatlantic.com/magazine/ archive/2014/06/the-case-for-reparations/361631/. Accessed 29 Oct 2020.

Collins, Sean. 2020. Trump once flirted with white nationalism. Now it's a centerpiece of his White House. Vox. https://www.vox.com/21313021/trump-white-nationalism-supremacy-miller-banno n-immigration. Accessed 29 Oct 2020.

Confessore, Nicholas. 2016. For whites sensing decline, Donald Trump unleashes words of resistance. New York Times. https://www.nytimes.com/2016/07/14/us/politics/donald-trump-white-identity. html. Accessed 29 Oct 2020.

Darity, William A., Jr., and A. Kirsten Mullen. 2020. From here to equality: reparations for Black Americans in the twenty-first century. Chapel Hill, NC: University of North Carolina Press.

Demerjian, Karoun. 2020. Trump threatens to veto military bill over Confederate-named bases, forcing a showdown with Republicans. Washington Post. https://www.washingtonpost.com/national-secur ity/trump-veto-confederate-bases/2020/07/21/9a45fa88-cb7b-11ea-91f1-28aca4d833a0_story.html. Accessed 29 Oct 2020.

Dias, Elizabeth. 2020. Christianity will have power. New York Times. https://www.nytim es.com/2020/08/09/us/evangelicals-trump-christianity.html. Accessed 29 Oct 2020.

Feinberg, Ayla, Regina Branton, and Valerie Martinez-Ebers. 2019. Counties that hosted a 2016 Trump rally saw a 226 percent increase in hate crimes. Washington Post. https://www.washingtonpost.com/ politics/2019/03/22/trumps-rhetoric-does-inspire-more-hate-crimes/?noredirect=on\#click=https://t. co/bYXsN60xzH. Accessed 29 Oct 2020.

Fies, Andy. 2020. Evanston, Illinois finds innovative solution to funding reparations: marijuana sales taxes. $A B C$ News. https://abcnews.go.com/US/evanston-illinois-finds-innovative-solution-fundingreparations-marijuana/story?id=71826707. Accessed 29 Oct 2020.

Franklin, John Hope, and Evelyn Higginbotham. 2010. From slavery to freedom: a history of African Americans, 9th ed. New York: McGraw-Hill.

Frymer, Paul. 2017. Building an American empire: the era of territorial and political expansion. Princeton: Princeton University Press.

Gambino, Lauren. 2020. Call for reparations are growing louder. How is the U.S. responding? The Guardian. https://www.theguardian.com/world/2020/jun/20/joe-biden-reparations-slavery-georg e-floyd-protests. Accessed 29 Oct 2020. 
Goldberg, Emma. 2020. How reparations for slavery became a 2020 campaign issue. New York Times. https://www.nytimes.com/2020/06/18/us/politics/reparations-slavery.html. Accessed 29 Oct 2020.

Gonyea, Don. 2017. Majority of White Americans say they believe Whites face discrimination. NPR. https://www.npr.org/2017/10/24/559604836/majority-of-white-americans-think-theyre-discrimina ted-against. Accessed 29 Oct 2020.

Google Trends. 2020. Reparations for slavery. https://trends.google.com/trends/explo re date $=$ all \&geo $=$ US\&q=\%2Fm\%2F01vp9c. Accessed 29 Oct 2020.

Greer, Allan. 2017. Property and dispossession. Cambridge: Cambridge University Press.

Hannah-Jones, Nikole. 2020. What is owed? New York Times Magazine. https://www.nytimes.com/inter active/2020/06/24/magazine/reparations-slavery.html. Accessed 29 Oct 2020.

Harris, Roger D. 2020. "Black Lives Matter" is international: where there is oppression, there will be resistance. Council on Hemispheric Affairs. https://www.coha.org/black-lives-matter-is-internatio nal-where-there-is-oppression-there-will-be-resistance/. Accessed 19 Oct 2020.

Hart, Gillian. 2020. Why did it take so long? Trump-Bannonism in a global conjunctural frame. GeografiskaAnnaler: Series B, Human Geography 102 (3): 239-266.

Henry, Charles P. 2003. The politics of racial reparations. Journal of Black Studies 34 (2): 131-152.

Henry, Charles P. 2007. Long overdue: the politics of racial reparations. New York: New York University Press.

Holden-Smith, Barbara. 1993. Lords of lash, loom, and law: justice story, slavery, and Prigg v. Pennsylvania. Cornell Law Review 78 (6): 1086-1151.

Holpuch, Amanda. 2019. Stephen Miller: the white nationalist at the heart of Trump's White House. The Guardian. https://www.theguardian.com/us-news/2019/nov/24/stephen-miller-white-nationalis t-trump-immigration-guru. Accessed 29 Oct 2020.

Hudson, Peter James. 2017. Bankers and empire: how Wall Street colonized the Caribbean. Chicago: University of Chicago Press.

Inskeep, Steve, Simone Popperl, and Lilly Quiroz. 2020. Former DHS official: White House failed to take right-wing extremism seriously. NPR. https://www.scpr.org/news/2020/09/02/94289/former-dhsofficial-white-house-failed-to-take-far/. Accessed 29 Oct 2020.

Jardina, Ashley. 2019. White identity politics. New York: Cambridge University Press.

Jardina, Ashley, and Michael Traugott. 2019. The genesis of the birther rumor: partisanship, racial attitudes and political knowledge. Journal of Race, Ethnicity and Politics 4 (1): 60-80.

Jones, Thai. 2020. Slavery reparations seem impossible. In many places, they're already happening. Washington Post. https:/www.washingtonpost.com/outlook/2020/01/31/slavery-reparations-seemimpossible-many-places-theyre-already-happening/?arc404=true. Accessed 29 Oct 2020.

Karni, Annie, Maggie Haberman, and Sydney Ember. 2020. Trump plays on racialized fears of terrorized suburbs to court white voters. New York Times. https://www.nytimes.com/2020/07/29/us/politics/ trump-suburbs-housing-white-voters.html. Accessed 29 Oct 2020.

King, Desmond, and Rogers M. Smith. 2005. Racial orders in American political development. American Political Science Review 99 (1): 75-92.

King, Desmond, and Rogers M. Smith. 2011. Still a house divided: race and politics in Obama's America. Princeton, NJ: Princeton University Press.

Kirby, Jen. 2020. "Black Lives Matter" has become a global rallying cry against racism and police brutality. Vox. https://www.vox.com/2020/6/12/21285244/black-lives-matter-global-protests-george-floyd -uk-belgium. Accessed 29 Oct 2020.

Langer, Gary. 2020. 63\% support Black Lives Matter as recognition of discrimination jumps: poll. $A B C$ News. https://abcnews.go.com/Politics/63-support-black-lives-matter-recognition-discriminationjumps/story?id=71779435. Accessed 29 Oct 2020.

Leadership Conference on Civil and Human Rights. 2020. Our work. August 10. https://civilrights.org/ our-work/. Accessed 29 Oct 2020.

Lee, Trymaine. 2020. Transcript: into Jamaal Bowman's insurgent run. Into America, NBC News. https ://www.nbcnews.com/podcast/into-america/transcript-jamaal-bowman-s-insurgent-run-n1233817. Accessed 29 Oct 2020.

Lillis, Mike, and Scott Wong. 2019. Reparations bill wins new momentum in Congress. The Hill. https:// thehill.com/homenews/house/437286-reparations-bill-wins-new-momentum-in-house. Accessed 29 Oct 2020 .

Liptak, Kevin, and Kristen Holmes. 2020. Trump calls Black Lives Matter a "symbol of hate" as he digs in on race. CNN Politics. https://www.cnn.com/2020/07/01/politics/donald-trump-black-lives-matte r-confederate-race/index.html. Accessed 29 Oct 2020. 
Movement for Black Lives. 2020. Policy platforms. M4BL. https://m4bl.org/policy-platforms/. Accessed 29 Oct 2020.

NAACP. 2020. NAACP strategic plan: game changes for the 21st century. NAACP. https://www.naacp .org/about-us/game-changers/. Accessed 29 Oct 2020.

Newburger, Emily. 2020. Breaking the chain. Harvard Law Bulletin. https://today.law.harvard.edu/featu re/breaking-chain/. Accessed 29 Oct 2020.

Peiser, Jaclyn. 2020. 'Their tactics are fascistic': barr slams Black Lives Matter, accuses the left of 'tearing down the system'. Washington Post. https:/www.washingtonpost.com/nation/2020/08/10/barrfox-antifa-blm/. Accessed 29 Oct 2020.

Pereira, Ivan. 2020. Asheville City Council approves reparations plan as Providence explores idea. $A B C$ News. https://abcnews.go.com/US/city-council-asheville-north-carolina-unanimously-approvesreparation/story?id=71795059. Accessed 29 Oct 2020.

Rickford, Russell. 2016. Black Lives Matter: toward a modern practice of mass struggle. New Labor Forum 25 (1): 34-42.

Robinson, Randall. 1999. The debt: what America owes to blacks. New York: The Penguin Group.

Rose, Max, and Ali H. Soufan. 2020. We once fought jihadists. Now we battle white supremacists. New York Times. https://www.nytimes.com/2020/02/11/opinion/politics/white-supremacist-terrorism. html. Accessed 29 Oct 2020.

Shaw, Adam. 2020. Trump ends "critical race theory" training for federal employees, calls it a "sickness". Fox News. https://www.foxnews.com/politics/trump-ends-critical-race-theory-training-feder al-employees. Accessed 29 Oct 2020.

Smith, Rogers M., and Desmond King. 2020. White protectionism in America. Perspectives on Politics. https://doi.org/10.1017/S1537592720001152.

Stanley-Becker, Isaac. 2020. As protests spread to small-town America, militia groups respond with armed intimidation and on-line threats. Washington Post. https://www.washingtonpost.com/natio nal/as-protests-spread-to-small-town-america-militia-groups-respond-with-online-threats-andarmed-intimidation/2020/06/18/75c4655e-b0a1-11ea-8f56-63f38c990077_story.html. Accessed 29 Oct 2020 .

Szetela, Adam. 2019. Black Lives Matter at five: limits and possibilities. Ethnic and Racial Studies 43 (8): $1358-1383$.

Trump, Donald J. 2016a. Remarks at Youngstown State University in Youngstown, Ohio. The American Presidency Project. https://www.presidency.ucsb.edu/documents/remarks-youngstown-state-unive rsity-youngstown-ohio. Accessed 29 Oct 2020.

Trump, Donald J. 2016b. Remarks at the Washington County park fair in West Bend, Wisconsin. The American Presidency Project. https://www.presidency.ucsb.edu/documents/remarks-the-washington -county-fair-park-west-bend-wisconsin. Accessed 29 Oct 2020.

Trump, Donald J. 2016c. Remarks at a rally at Sun Center Studios in Chester Township, Pennsylvania. The American Presidency Project. https://www.presidency.ucsb.edu/documents/remarks-rally-suncenter-studios-chester-township-pennsylvania. Accessed 29 Oct 2020.

Trump, Donald J. 2016d. Remarks at the Cleveland Arts and Sciences Academy in Cleveland, Ohio. The American Presidency Project. https:/www.presidency.ucsb.edu/documents/remarks-the-clevelandarts-and-social-sciences-academy-cleveland-ohio. Accessed 29 Oct 2020.

Trump, Donald J. 2016e. Addressing accepting the presidential nomination at the Republican National Convention in Cleveland, Ohio. The American Presidency Project. https://www.presidency.ucsb. edu/documents/address-accepting-the-presidential-nomination-the-republican-national-convention -cleveland. Accessed 29 Oct 2020.

Trump, Donald J. 2016f. Remarks at Great Faith International Ministries in Detroit, Michigan. The American Presidency Project. https://www.presidency.ucsb.edu/documents/remarks-great-faith -international-ministries-detroit-michigan. Accessed 29 Oct 2020.

Trump, Donald J. 2016g. Remarks to the 11th annual values voter summit in Washington, D.C. Omni Shoreham Hotel. The American Presidency Project. https://www.presidency.ucsb.edu/documents/ remarks-the-11th-annual-values-voter-summit-washington-dc-omni-shoreham-hotel-washington. Accessed 29 Oct 2020.

Trump, Donald J. 2020a. Remarks by President Trump at South Dakota's 2020 Mount Rushmore fireworks celebration. WhiteHouse.gov. https://www.whitehouse.gov/briefings-statements/remarkspresident-trump-south-dakotas-2020-mount-rushmore-fireworks-celebration-keystone-south-dakot a/. Accessed 29 Oct 2020 . 
Trump, Donald J. 2020b. Full text: President Trump's 2020 RNC acceptance speech. NBC News. https ://www.nbcnews.com/politics/2020-election/read-full-text-president-donald-trump-s-acceptance -speech-rnc-n1238636. Accessed 29 Oct 2020.

Wise, Justin. 2020. Support for Black Lives Matters dips 9 percent since June: poll. The Hill. https://thehi 11.com/homenews/514749-support-for-black-lives-matter-off-9-points-since-june-poll. Accessed 29 Oct 2020 .

Worland, Justin. 2020. America's long overdue awakening to systemic racism. Time. https://time. com/5851855/systemic-racism-america/. Accessed 29 Oct 2020. 